\title{
Diversification discount or premium? New evidence from BITS establishment-level data
}

\author{
Belén Villalonga \\ The Anderson School at UCLA \\ 110 Westwood Plaza, Box 951481 \\ Los Angeles, CA 90095-1481, U.S.A. \\ Tel.: (310)-470-2623 \\ Fax: (310)-470-0643 \\ e-mail: belen.villalonga@anderson.ucla.edu \\ web: http://personal.anderson.ucla.edu/belen.villalonga
}

First draft, July 2000. This draft, November 2000.

I wish to thank my dissertation co-chairs, Richard Roll and Richard Rumelt, and the rest of my committee--Harold Demsetz, Guido Imbens, Matthias Kahl, Bill McKelvey, and William Ouchi--for their support and many helpful discussions. Thanks also to Judith Chevalier, Richard Makadok, Anita McGahan, and Olav Sorenson for their comments and suggestions. Thanks to Nelson Lim for his help at the Census data lab. Financial support from the Fulbright Commission, Fundación Caja de Madrid, Fundación Ramón Areces, UCLA's Graduate Division, and the California Census Research Data Center (CCRDC) is also gratefully acknowledged. The research in this paper was conducted while the author was a research associate at the CCRDC in association with the Center for Economic Studies of the U.S. Bureau of the Census. Research results and conclusions expressed are those of the author and do not necessarily indicate concurrence by the Bureau of the Census, the Center for Economic Studies, or the CCRDC. All errors remain mine. 


\title{
Diversification discount or premium? New evidence from BITS establishment-level data
}

\begin{abstract}
This paper examines whether the finding of a diversification discount in U.S. stock markets is only a data artifact. Segment data may give rise to biased estimates of the value effect of diversification because segments are defined inconsistently across firms, and that inconsistency does not occur at random. I use a new establishment-level database that covers the whole U.S. economy (BITS) to construct business units that are more consistently and objectively defined across firms, and thus more comparable. Using a common methodological approach on a sample of firms which exhibit a diversification discount according to segment data, I find that, when BITS data are used, diversified firms actually trade at a significant average premium. The premium is robust to variations in the method, sample, business unit definition, and measures of excess value and diversification used.
\end{abstract}

Key words: Diversification discount, premium, Tobin's $q$. 
Several studies indicate that diversified firms trade at an average discount relative to specialized firms in the same industries, and that they have been doing so for several decades (Lang and Stulz, 1994; Berger and Ofek, 1995; Servaes, 1996). Yet, a substantial part of economic activity continues to be carried out within diversified firms. Between 1990 and 1996, for instance, diversified firms were home to nearly $50 \%$ of U.S. employment, and owned about $60 \%$ of the total assets of firms trading in U.S stock markets. ${ }^{1}$ Furthermore, and despite the emphasis placed on corporate refocusing by recent literature, firms have actually continued to engage in nearly as much diversification as refocusing during the past two decades. ${ }^{2}$ In fact, Hatfield, Liebeskind, and Opler (1996) show that all this corporate restructuring over the 1980s has resulted in lower, rather than higher, aggregate industry specialization.

The finding of a "diversification discount" thus raises an important economic puzzle: Are the forces of competition so weak, and capital markets so inefficient, that they consistently fail to eliminate diversified firms, despite these firms' relative inefficiency? The finding is also puzzling because it conflicts with most of the earlier evidence about the effect of diversification on corporate performance-whether measured as profitability (Montgomery, 1994; Barney, 1996), productivity (Schoar, 2000), or even stock market performance in the form of abnormal returns to announcements of diversifying acquisitions. ${ }^{3}$

This paper seeks resolution to the puzzle by investigating the possibility that the diversification discount is simply a data artifact. The use of segment data introduces noise in

\footnotetext{
${ }^{1}$ Source: Author's own computations, based on Census (Business Information Tracking Series) and Compustat data.

${ }^{2}$ The Compustat segment files show that, for every 100 firms that reduced their number of segments in any year between 1991 and 1997, 88 increased their number of segments. A similar figure (82\%) is reported by Hyland (1997) for the 1977-1992 period.

${ }^{3}$ Studies reporting positive market reactions to unrelated diversifying acquisitions include Schipper and Thompson (1983) and Hubbard and Palia (1999) for the 1960s, Matsusaka (1993) for the late 60s and 70s, and Hyland (1997) and Chevalier (1999) for the 80s and 90s. As an exception to this finding, Morck, Shleifer, and Vishny (1990) report a negative market reaction to this type of acquisitions in the 1980s.
} 
prior estimates of diversification's effect on firm value because it breaks down the activities of firms by industries inconsistently across firms. I argue that this inconsistency is not random, but that, partly by institutional design, and partly because of managerial discretion, diversified firms aggregate their different activities into reportable segments in ways that may make them appear as artificially low performers relative to single-segment firms in the same industries. As a result, segment data introduces a systematic bias in prior estimates of diversification's value effect, which are thus more negative than those that would otherwise be obtained.

I use the Business Information Tracking Series (BITS), a new Census database that covers the whole U.S. economy at the establishment level, to assess my claim. BITS data allow me to construct business units that are more consistently defined across firms, and therefore more comparable. I use a common sample of firms and a common method (Lang and Stulz's "chop shop" approach) to compare the estimates of diversification's value effect obtained from breaking down firms' activities according to BITS business units vs. Compustat segments. Consistently with earlier studies, I find a diversification discount when firms' activities are broken down into Compustat segments. However, and consistently with my own arguments, I also find that when the same firms' activities are broken down into BITS business units, diversified firms trade at a significant average premium with respect to comparable portfolios of single-business firms.

This paper adds to the growing body of research about the diversification discount by questioning what has hereto been a maintained assumption in the literature. Namely, that segment data are valid for the purpose of estimating the value effect of diversification. The puzzle raised by the finding of a diversification discount has triggered an active debate in the corporate finance literature. On one side of the debate are those who have interpreted the 
discount as evidence that diversification destroys value, ${ }^{4}$ and set to explain why this might be the case. The explanations offered largely fall into two groups: agency behavior, and inefficient internal capital markets. Neither of them, however, seem to be fully supported by empirical evidence. Denis, Denis, and Sarin (1997) document a negative relation between the level of diversification and the equity ownership of both insiders and outside blockholders, which they interpret as evidence of agency costs. However, they find no relation between any of these ownership structure variables and the value loss from diversification as estimated by Berger and Ofek's measure.

The inefficient internal capital markets explanation initially found support in a group of studies that documented inefficient investment patterns across divisions of diversified firms (Lamont, 1997; Shin and Stulz, 1998; Scharfstein and Stein, 1997; Scharfstein, 1998; Wulf, 1999; Rajan et al., 2000). However, later studies have uncovered two different sources of bias that seriously undermine the former's conclusions. Whited (1999) shows that the method common to these studies suffers from a measurement error problem which, when corrected, leads to the disappearance of all evidence of inefficient capital allocation across divisions. Chevalier (1999) shows that the investment patterns that had been attributed to value-destroying crosssubsidization are apparent between pairs of merging firms prior to their mergers, thus providing evidence of a sample selection bias in prior literature. In addition, Maksimovic and Phillips (1999) provide plant-level data evidence that is consistent with efficient internal capital markets.

On the other side of the debate are those who acknowledge that the fact that diversified firms trade at a discount does not necessarily imply that the discount is attributable to valuedestroying diversification. For instance, Matsusaka (1998) proposes a dynamic model of

\footnotetext{
${ }^{4}$ For instance, Berger and Ofek in a later paper claim that "[Berger and Ofek (1995)] find that, during 1986-1991, the average diversified firm destroyed about 15 percent of the value its lines of business would have had if operated
} 
diversification in which firms repeatedly enter new businesses and exit old ones in search of good matches for their organizational capabilities. In his view, the discount emerges because diversified firms are effectively being compared only to those specialized firms that have already found good matches, whereas specialized firms that have not yet found a good match are likely to be underrepresented in most samples. Fluck and Lynch (1999) argue that conglomerate mergers may temporarily increase the combined values of acquirers and targets by financing positive net present value projects that cannot be financed as stand-alones due to agency problems. If and when profitability improves, the financing synergy ends and it becomes efficient for the acquiror to divest the target. Bernardo and Chowdry (1999) note that diversified firms may trade at a discount precisely because the market value of non-diversified firms reflects the real options value of diversification, whereas diversified firms have perhaps exhausted their options to diversify and expand. Zuckerman (1999), based on his finding that the discount is related to the extent to which diversified firms are not covered by the analysts specializing in their industries, argues that it is these firms' failure to be considered legitimate members of their industries that gives rise to what he renames as the "illegitimacy discount". Burch, Nanda, and Narayanan (2000) see diversification as the optimal response to industry shocks of less innovative firms. The discount in their view arises because of the relatively weaker position of firms that choose to diversify in an industry, and not because of diversification itself. ${ }^{5}$

Several empirical studies have yielded direct support for this side of the debate, in addition to those already mentioned. These studies note that prior estimates of the diversification discount suffer from a sample selection bias, due to the fact that diversification is not random.

as stand-alone businesses" (1996: 1175).

${ }^{5}$ Note that these theories are not inconsistent with theories and evidence about the causes and consequences of corporate refocusing (Liebeskind and Opler, 1992; Comment and Jarrell, 1995; John and Ofek, 1995; Daley, 
Particularly, Hyland (1997), Campa and Kedia (1999) and Villalonga (1999) find that diversified firms traded at a discount prior to diversifying. Moreover, the latter two also show that, when the selection bias is corrected for, the diversification discount as such disappears or even turns into a significant premium. Relatedly, Graham, Lemmon, and Wolf (1999) show that half or more of the diversification discount appears because the business units acquired by diversifying firms were also discounted prior to their acquisition.

The present study takes the skepticism towards the diversification discount one step further by questioning the finding itself, not just its interpretation. Indeed, my finding that the use of a more objective and fine-grained source of data reverses the fundamental result about the relative value of diversified firms calls into question much of the received wisdom about the diversification discount, as well as the adequacy of segment data for large sample research within firms.

The rest of the paper is organized as follows. Section 1 explains why the use of segment data may be problematic for a study of diversification and its effect on corporate value. Section 2 describes the data and variables. Section 3 presents and discusses the results. Section 4 concludes.

\section{Problems with using segment data to estimate diversification's value effect}

\subsection{Noise}

All the studies that have reported the existence of a discount to corporate diversification in U.S. stock markets since the late 1970s have used Compustat segment data to breakdown a firm's activities by industry and construct measures of diversification and its effect on corporate value. However, the use of segment data for these purposes raises a number of concerns.

Mehrotra, and Sivakumar, 1997, Berger and Ofek, 1999; Schlingemann, Stulz, and Walkling, 1999; Matsusaka and 
First, it is widely acknowledged that the extent of disaggregation in segment financial reporting is much lower that the "true" extent of a firm's industrial diversification (Lichtenberg, 1991; AIMR, 1993; AICPA, 1994). Moreover, Lichtenberg (1991) reports that this difference has been increasing over time. The difference emerges partly by design, since firms are required by the Financial Accounting Standards Board (FASB) to report disaggregated information for segments that represent $10 \%$ or more of its consolidated sales, assets, or profits. Hence, regardless of how appropriate the $10 \%$ threshold may be for the purpose of disclosing financial information, from a diversification research point of view it means that the number of different industries a firm may be identified as being in is right-censored at 10. In contrast, those sources that do not impose such censoring on the data show that the number of 4-digit SIC codes in which a firm is present may be as high as 133 , and that the percentage of firms present in more than 10 industries may be as high as $17 \%$ for all Compustat firms (Lichtenberg, 1991) or 56\% for the 500 largest U.S. public companies (Montgomery, 1994). ${ }^{6}$

In addition, because managers have considerable discretion in disclosing segment-level information, the number of segments actually reported by some firms seems to have fallen even beneath the threshold that the FASB intended to establish through its Statement of Financial Accounting Standards (SFAS) 14. Indeed, the small number of segments reported by some firms was one of the major concerns that triggered the issuance of SFAS 131 in 1997, which has come to supercede SFAS 14 as the rule-setting satement for segment reporting (AIMR, 1993; AICPA, 1994). ${ }^{7}$ The implementation of SFAS 131 is expected to result in a greater number of segments

Nanda, 2000).

${ }^{6}$ Sources: Business Information Tracking Series (1989-1996) for the 133 figure, and Compustat SIC File for 1985, for both Lichtenberg's and Montgomery's figures.

${ }^{7}$ For instance, the Association for Investment Management Research stated that "FAS 14 requires disclosure of lineof-business information classified by 'industry segment'. Its definition of segment is necessarily imprecise, recognizing that there are numerous practical problems in applying that definition to different business entities 
reported by at least certain firms (FASB 1997). In fact, some early evidence confirms this has actually been the case, with $12 \%$ to $37 \%$ increases in the average number of segments reported by large firms in 1998 relative to 1997 (Herrmann and Thomas, 2000; Street, Nichols, and Gray, 2000). Unfortunately, these improvements do not affect diversification discount studies, whose sample periods are all previous to 1997 . But because the $10 \%$ materiality threshold for segment definition is maintained in SFAS 131, the extent of disaggregation in segment data will anyhow continue to be much lower than firms' true extent of diversification.

A second concern raised by the use of segment data for a study of corporate diversification arises from the definition of segment itself. SFAS 14 defines a segment as "a component of an enterprise engaged in providing a product or service or a group of related products and services primarily to unaffiliated customers (i.e. customers outside the enterprise) for a profit." Hence, segments may by definition be an aggregation of two or more activities, vertically or otherwise related. In my sample, for instance, the average number of different SIC codes per segment is 4 . What is worse from the point of view of a diversification researcher is that, for any given segment SIC code, the aggregation of activities into the segment differs from firm to firm. The problem is exacerbated by the fact that segments are self-reported. That is, segments are identified by name by the reporting company, and are assigned a primary (and, in some cases, a secondary) 4digit SIC code by Compustat staff. For instance, Davis and Duhaime (1992) find that, in 5 to 10 per cent of cases, businesses which were neither related nor vertically

operating under disparate circumstances. That weakness in FAS 14 has been exploited by many enterprises to suit their own financial reporting purposes. As a result, we have seen one of the ten largest firms in the country report all its operations as being in a single, very broadly defined industry segment" (AIMR, 1993: 60). In the same spirit, the American Institute of Certified Public Accountants Special Committee stated that "[users] believe that many companies define industry segments too broadly for business reporting and thus report on too few industry segments" (AICPA, 1994: 69). 
integrated from the perspective of Compustat staff had been grouped into a segment by the firms. ${ }^{8}$ A question therefore arises as to the comparability of segments across firms.

A third concern is that firms sometimes change the segments they report for without there being any real change in their operations. These reporting changes occur with notable frequency: Denis, Denis, and Sarin (1997), and Hyland (1997) find that about one fourth of the changes in Compustat firms' number of segments are purely reporting changes, as opposed to real instances of diversification or refocusing. Therefore, the inconsistency in segment definitions occurs not only across firms, but also within firms over time.

The three concerns identified suggest that the use of segment data introduces noise at several points in the estimation of the value effect of diversification. One, firms that are present in more than one industry may get misclassified as non-diversified (these would be "singlesegment but multi-business" firms). Two, firms may be misallocated to industries, and industries may be misallocated to firms. Three, the industry mean or median market values or $q$ 's that serve as benchmarks for the valuation of segments may be equivocal, since only single-business firms are supposed to be included in the computation but in practice those "single-segment multibusiness" firms also are. As a result of all this, segment data-based estimates of the diversification discount may be very different from those that would be obtained if firms' true extent of diversification were measured.

\subsection{Bias}

The fundamental question raised by the preceding discussion is whether or not the segment data-based estimates of diversification's value effect are systematically biased in one

\footnotetext{
${ }^{8}$ They also provide a detailed analysis of the issues raised by segment data for research on diversification, vertical integration, and industrial organization in general.
} 
direction or another. In other words, are the variations in the definition of diversification resulting from segment data systematically related to variations in firm value?

As noted before, the problem of the small number of segments reported relative to a firm's true extent of diversification is partly due to institutional design (materialized in FASB rules), and partly due to the managerial discretion allowed for by such rules. If there were no managerial discretion, only firms with more than ten different activities would be bound by the institutional constraint. Hence, no multi-business firms would be misclassified as singlesegment, and hence, the industry mean and median market values would be unaffected. Some misallocation of firms to industries and viceversa would remain, but there is no particular reason to expect a bias from such misallocation. Moreover, a common finding to many studies of the diversification discount is that the discount is only significant between one and two-segment firms, but not between two-segment firms and firms with larger numbers of segments. Therefore, to the extent to which the difference between the firm's reported and true number of distinct businesses is institutionally designed, such difference should not be expected to yield neither lower nor higher estimates of the value effect of diversification.

In contrast, the institutional part of the problem of segment definition (the second concern identified above) may not be innocuous to the estimated value effect of diversification. Firms are purposely allowed to group related activities into a common segment. As a result, firms with tightly related activities might be classified as undiversified according to segment data, but as diversified in a more disaggregated data source. The cumulative evidence about diversification and performance in the form of accounting profitability unequivocally suggests that related diversification is positively associated to profitability while unrelated diversification is negatively associated to it; or that diversification and performance follow a non-monotonic 
relationship (Rumelt, 1974; Barney, 1996). ${ }^{9}$ Berger and Ofek's (1995) findings suggest that this is also the case when performance is measured as excess value from diversification. Therefore, by shifting those high-performing related diversifiers from the diversified to the undiversified firms category, segment data are effectively biased towards finding a (greater) discount to diversification than what should otherwise be found.

The latitude given to and exercised by managers in segment reporting is also likely to bias estimates of diversification's value effect. Game-theoretic models in accounting about a firm's disclosure choices in the presence of a competitor suggest that (a) high-performing firms are less prone than low performers to disclosing financial information (Darrough and Stoughton, 1990; Feltham and Xie, 1992); (b) high performers are less prone than low performers to report segment (vs. aggregate) data (Feltham, Gigler, and Hughes, 1990); and (c) diversified firms aggregate their different activities into reportable segments so as to avoid disclosing information to potential competitors about which if its operations are most lucrative (Hayes and Lundholm, 1996). If this is the case, then, in high-performance industries the segments of diversified firms will appear to be worse performers than what they actually are, and also worse performers than what segments of undiversified firms are (since these firms, unlike their diversified counterparts, do not have a choice about how to aggregate their activities into segments). Therefore, segment data will be unduly prone to yield a discount for diversified firms relative to undiversified firms.

Hayes and Lundholm's model also predicts that different activities will be reported as separate segments when each activity's results are sufficiently similar, but will be aggregated into one segment when the results are disparate. This suggests an additional reason for firms to group related activities into a common segment, and hence for segment data to be biased towards

\footnotetext{
${ }^{9}$ Barney (1996: 388-389) provides a summary table with 30 studies that have replicated this original finding of Rumelt (1974).
} 
finding a more negative effect of diversification on firm value. Harris (1998) undertakes an empirical investigation of how firms choose their reported segments. As predicted by Hayes and Lundholm, she finds that firms are less likely to disclose segments separately when (a) they are consistently earning abnormal profits, and (b) when there is intra-firm heterogeneity in earnings persistence. Her results therefore confirm the two reasons for concern just mentioned.

In addition, the frequency of segment reporting changes not justified by diversification or refocusing activities seems to suggest that the inconsistency of segment definitions over time within a given firm is not an accidental occurrence either. The longitudinal implication of the theoretical accounting models mentioned is that firms change their reported segments for a variety of reasons, and particularly as a function of their profitability prospects. Anecdotal evidence also indicates this is the case: Springsteel quotes the Director of Accounting and SEC Technical Services at Coopers \& Lybrand as saying “I've heard innuendo that some companies may make some internal reporting changes to get the segment groupings they want, mostly to reduce competitive harm" (1998: 85). Piotroski (2000) investigates the causes and consequences of discretionary segment reporting decisions on a panel data set and finds that segment reporting fineness is indeed negatively related to profitability, both cross-sectionally and longitudinally.

In summary, there are multiple reasons to believe that segment data-based estimates of diversification's value effect are systematically biased in the direction of yielding a more negative excess value (i.e. more of a discount) for diversified firms than what they actually have. In the rest of the paper I use establishment-level data to empirically assess this claim.

\section{Data and variables}

\subsection{Data and sample}


Two different databases, Compustat segment-level files, and the U.S. Census Bureau's Business Information Tracking Series (BITS), are used to construct the sample for this study, as well as to determine the proportion of each firm's activities by industry. In addition, Compustat's company-level files are used to obtain data on firms' market values. Because of the centrality of the BITS data to this paper, and because it is the first study to use this new Census database, a relatively more detailed description of it is in order. ${ }^{10}$

BITS provides establishment-level panel data between 1989 and 1996 for all U.S. private sector establishments with positive payroll in any of those years, from both public and private firms. It includes a total of 50,708,528 establishment-year observations from 41,203,605 different firm-years. The database has been constructed by the U.S. Bureau of the Census under contract to the Office of Advocacy of the U.S. Small Business Administration, and is documented in Robb (2000). A preliminary version of BITS, which covered only three years and a slightly different set of variables and was then called the Longitudinal Enterprise and Establishment Microdata (LEEM), has been documented by Acs and Armington (1998) and used in Armington (1998), Armington and Robb (1998, 1999), and Acs, Armington and Robb (1999).

The basic unit of analysis in BITS is the business establishment, defined as "a single physical location where business is conducted or where services or industrial operations are performed". For each establishment-year observation, BITS provides information on its employment, annual payroll, primary 4-digit SIC code, location, start year, the firm and legal entity to which the establishment belongs, and the firm's total employment. Each establishment in BITS is identified yearly by a Census File Number $(C F N)$ and tracked through time using a permanent identifier which remains unchanged even if the $C F N$ changes as a result of sructural,

\footnotetext{
${ }^{10}$ Several research projects based on BITS are currently underway at the Census Bureau and at the Small Business Administration. However, my study is, to my knowledge, the first that has been completed using this database.
} 
legal, or ownership changes in the business. Establishments are owned by legal entitiestypically corporations, partnerships, or sole proprietorships-, which are identified (if they have employees) by a federal Employer Identification Number (EIN). A firm in BITS is defined as "the largest aggregation of business legal entities under common ownership and control". ${ }^{11}$ Hence, firms may be composed of one or more legal entities, each of which may in turn own one or more establishments.

BITS provides the greatest coverage ever offered by an intra-firm level database, since it contains data on the entire population of U.S. establishments from all sectors of the economy, excluding farms (SIC 01-02), railroads (SIC 40), the Postal Service (SIC 43), private households (SIC 88), and large pension, health, and welfare funds (SIC 6371 with at least 100 employees). Note that the coverage of all sectors of the economy as opposed to just manufacturing is particularly important for a study of diversification. For instance, of the 6,167 diversified (multisegment) firms included in Compustat segment files, less than $20 \%$ are manufacturing-only, 56\% are non-manufacturing only, and $24 \%$ are diversified across both sectors. Furthermore, $60 \%$ of the cross-sector diversifiers have less than $50 \%$ of their assets in manufacturing. Hence, the representativeness of a sample of diversified firms may be seriously compromised if only manufacturing establishments are considered.

Due to its advantages of (1) being disaggregated to the establishment level-thus allowing the researcher to determine the breakdown of firms' activities by industry in a consistent way across firms, (2) covering all sectors of the economy, and (3) having establishments longitudinally linked, BITS can be considered the best source of data that is currently available for the study of corporate diversification in the U.S. One caveat, however, is

\footnotetext{
11 For the Census Bureau, a firm (Firm A) owns another firm (Firm B) if either of two basic criteria are met: (1)
} 
that BITS provides very little information beyond that which may be used to construct better measures of diversification. For example, it contains no performance data whatsoever, particularly stock market values as required to study the diversification discount, which is why it has been merged with Compustat company-level data for this paper. Villalonga (2000) includes a comparison of BITS with other large-sample databases that have been or may be used for academic research within firms. ${ }^{12}$

The BITS-Compustat Common Sample (so called hereafter) which constitutes the sample for this study has been constructed by merging both databases to the extent to which this is feasible. Since Compustat covers all firms that are publicly traded in U.S. stock markets, the firms in the Common Sample are, by intersection, firms that were publicly traded in a U.S. stock exchange and had at least one establishment in the U.S. in any year between 1989 and 1996.

EIN is the only common data field that may be used to match firms using a computer program, but doing so involves several issues. First, the Compustat company files include the firm's (primary) EIN, which is time-invariant for any given firm. Some multi-unit firms in BITS, however, comprise more than one EIN. Hence, in order to retrieve from BITS all of a firm's establishments one has to retrieve first the firm's Census identification number(s) associated to the firm's primary EIN. Second, BITS includes the establishment's EIN, but only the one it had in 1992. This raises two problems that introduce some additional complication in the data merging process. One, by matching only on EIN, those firms that did not exist in 1992 are left out of the Common Sample. Two, an establishment's EIN may change over time as a result of

Firm A owns more than $50 \%$ of the voting stock of Firm B, or (2) Firm A has the power to direct the management and policies of Firm B (Nguyen, 1998, p.7).

12 These include: Compustat segment-level data, the FTC Line-Of-Business data, the Strategic Planning Institute's PIMS data, the U.S. Census Bureau's Longitudinal Research Database (LRD), and Trinet's Large Establishment Database. 
changes in its ownership structure or legal form of organization. Thus, a direct matching on EINyear would attribute some establishments in some years to the wrong owner.

Similar problems arise if one attempts to merge Compustat and BITS using names. BITS itself contains no names, but establishment names can be retrieved from the Business Master Files of the Standard Statistical Establishment List (SSEL), from which BITS actually derives. However, those files are also only available for 1992 (and earlier Census years not in BITS).

In order to deal with these issues, a fairly complicated data merging process has been followed, which is documented in detail in Villalonga (2000). The process involves computermatching on EINs, hand-matching on names, and the use of two auxiliary Census databasesSSEL and the Longitudinal Research Database (LRD). For the purpose of this paper, it suffices to note that the series of merging operations performed maximize the number of feasible matches without misallocating establishment-year observations across their owning firms.

The resulting BITS-Compustat Common Sample is composed of 2,054,978 establishment-year observations from 22,814 different firm-years and 3,973 different firms. For this study, all of a firm's establishments with a common SIC code have been aggregated into "business units". This is the BITS-based unit of analysis equivalent to Compustat's segments, in the sense of representing a firm's activities in an industry. In contrast to segments, however, business units are constructed in a way that makes them comparable across firms, and the number of business units a firm may have is not limited to 10 . In fact, the maximum number of business units within a firm is 133 , and the average number of business units per segment in the Common Sample is 4 . The average number of establishments per business unit is 15 , the average number of establishments per firm is 90, and the average number of business units per firm is 6 for all firms, or 8 for diversified firms only. In contrast, the average number of segments per firm 
in the sample is 1.5 (1.2 for all Compustat firms in the same period), or 2.8 for diversified firms only (in both Compustat and the Common Sample).

Table 1 reports the number of firms, segments, business units, and establishments included in the Common Sample along with those in BITS and Compustat during the same period (1989-1996). It thus enables a comparison of the coverage and extent of disaggregation of firms' activities across the three databases. Clearly, the coverage of BITS is not just different but also much greater than that of Compustat, which is in turn much geater that that of the Common Sample. Nonetheless, with 3,973 firms and 8 years of data, the latter is still a considerably large panel that lends itself to rigorous statistical analysis. Moreover, the number of BITS business units belonging to the Common Sample firms, which is nearly five times as large as the number of Compustat segments in the same firms, indicates a large information gain from combining both raw data sources.

\section{Insert Table 1 about here}

Table 2 reports the average number of firms in the three databases by number of segments, business units, or both. Of most relevance for the purpose of this paper is the comparison between the business unit and segment breakdowns within the Common Sample, i.e. between columns 4 to 8 . Particularly, the able shows that as much as $42 \%$ of the sample firms switch from the undiversified to the diversified group when one moves from a segment breakdown of firms to a business unit breakdown. This is important because the reasons that lead me to expect a negative bias in segment-based estimates of the diversification discount apply mostly to the extent to which there is such a group switch. The table also indicates that the " 10 units maximum" institutional constraint is binding for a considerable number of firms (17\% of the firms have 10 or more business units). However, a large part of the difference between firms' 
reported and "true" extent if diversification seems attributable to factors that may generate a bias in estimates of the discount (managerial discretion, plus the institutional part of the problem of segment definition). Unfortunately, because a direct mapping between the segments and business units of diversified firms is not feasible, the difference cannot be apportioned among its originating factors in a more precise way.

\section{Insert Table 2 about here}

Table 3 shows additional descriptive statistics about the Common Sample as compared to the original samples in BITS and Compustat, including firms' average employment, assets, and Tobin's $q$ in each year. It thus offers a more complete picture of the comparability of the three samples than the previous two tables. Indeed, this table makes strikingly clear that the average firm in the Common Sample is very different from that in BITS: Because $99 \%$ of the firms in BITS employ only 10 people on average, the mean employment figure for the whole BITS sample is as low as 19, whereas the average firm in Compustat or in the Common Sample approximately employs 6,000 people. $^{13}$ The table also shows that the firms in the Common Sample are somewhat larger, but similar in size to those in Compustat when size is measured by employment (6,545 vs. 5,981, respectively). However, if size is measured by assets, the Common Sample firms, and particularly the single-segment group, are much smaller than those in Compustat (1,221 vs 2,122 millions of dollars for all firms; 483 vs.1,630 for single-segment firms). The (unadjusted) $q$ 's are also relatively smaller in the Common Sample (2.0 vs. 2.7).

Insert Table 3 about here

\footnotetext{
${ }^{13}$ The table also reveals some discrepancies between BITS and Compustat figures for employment, which is the only variable in common between both databases. Although both measures of employment are highly correlated (0.77), the differences are statistically significant.
} 
Following previous studies of the diversification discount, I initially eliminate from the sample for the computation of diversified firms' average excess value those firms with segments or business units in financial services (which would require a different valuation model from those that have become standard in this literature), and those firms whose imputed $q$ (as defined below) is higher than four times or lower than a fourth of their real $q$. However, because such eliminations may raise a reasonable concern about sample selection bias, I later re-estimate excess values without such eliminations as well.

\subsection{Variables}

The two most important variables for this study are excess value and diversification. A firm's individual excess value is measured in two different ways. First, following Lang and Stulz (1994), Servaes (1996), and Rajan et al. (2000), it is computed as the difference between a firm's Tobin's $q$ and its imputed $q$. Tobin's $q$ is proxied by the ratio of the market value of common equity plus the book value of preferred stock and debt to total assets. ${ }^{14}$ Imputed $q$ is the sizeweighted average of the hypothetical $q$ 's of the firm's segments (or business units), where a segment's (business unit's) hypothetical $q$ is taken to be the average of the single-segment (single-business) firms in the industry in the year examined. The size variables used as weights are assets or employment for segments, and employment for business units. Industry averages are first computed at the 4 digit-SIC code level, resorting to 3 or 2 digit averages when the more precise ones are not available. Then, as a robustness check, the excess value measures are recomputed using 3-digit SIC-based industry averages.

The second measure of excess value used is the natural logarithm of the ratio of the firm's $q$ and its imputed $q$. This measure is more similar to that used by Berger and Ofek (1995) 
and has been used by Schoar (2000) to compare the excess value estimates obtained from LRD data against those obtained from segment data. In this paper it is used as a robustness check on the validity of the results from the other measure, and to facilitate the comparison with this second group of studies.

The primary measure of diversification used is a multi-segment or a multi-business dummy, depending on the data. This dichotomous treatment of diversification follows once again prior research about the diversification discount, where it is justified by the fact that the discount of diversified firms found by Lang and Stulz (1994) and later studies is only significant between one and two-segment firms, but not between two-segment firms and firms with increasing numbers of segments. ${ }^{15}$ I use this as my primary measure of diversification for comparability with the diversification discount literature. Nonetheless, because this measure entails a very simplistic view of diversification, several other measures are later used to validate the results obtained on business unit data. These include the number of segments (or business units) in the firm, and four different continuous measures: a Herfindahl index, and the three entropy measures - total, related, and unrelated. ${ }^{16}$ These continuous measures are described in detail in Jacquemin and Berry (1979) and are standard in the vast strategy and economics literature on diversification that preceded the "diversification discount" stream.

In addition to excess value and diversification, several other variables enter the analyses either as controls or as independent variables in the propensity equation of the sample selection

\footnotetext{
${ }^{14}$ This measure, which is really a market-to-book ratio, is being increasingly used to avoid the arbitrary assumptions about depreciation and inflation rates that more sophisticated measures of $q$ require. Chung and Pruitt (1994) find that this proxy explains at least $96.6 \%$ of the variability of Lindenberg and Ross's (1981) measure of Tobin's $q$.

${ }^{15}$ This result also holds for my sample of this study and is available upon request.

${ }^{16}$ If $P_{i}$ is the proportion of a firm's assets in industry $i$, the Herfindahl index of diversification is $\mathrm{H}=\Sigma_{i} P_{i}{ }^{2}$, and the Total Entropy measure is $\mathrm{E}_{\mathrm{T}}=\boldsymbol{\Sigma}_{i} P_{i} \ln \left(1 / P_{i}\right)$. Both measures are computed at the 4digit SIC level. Unrelated Entropy, $\mathrm{E}_{\mathrm{U}}$, is defined like $\mathrm{E}_{\mathrm{T}}$ but computed at the 2-digit SIC level. Related Entropy is defined as $\mathrm{E}_{\mathrm{R}}=\mathrm{E}_{\mathrm{T}}-\mathrm{E}_{\mathrm{U}}$.
} 
model. The variables included as controls in the multivariate regressions of excess value on diversification are firm size (measured as the natural logarithm of assets), which has turned out as significant in all prior studies of the diversification discount, as well as the ratios of EBIT to sales and capital expenditures to sales. These are the control variables considered by Berger and Ofek (1995) and Campa and Kedia (1999), which I adopt for comparability with their studies.

\section{Results}

\subsection{Do the results on segment data obtain on business unit data?}

To ensure that my sample is comparable to those used in prior studies of the diversification discount, before proceeding to estimate the excess value of diversified firms on business unit data I verify whether the finding of a discount on segment data also holds for the Common Sample. For this purpose, I estimate the average excess value of multi-segment firms relative to single-segment firms, following Lang and Stulz (1994), Servaes (1996), and Rajan et al. (2000), as the mean difference between both groups of firms (or equivalently, as a univariate regression of the first measure of excess value described above on the multi-segment dummy).

Table 4 reports the estimates obtained at both levels of analysis. The first column shows that, consistent with prior studies, when excess values are estimated on segment data, the multisegment firms in my sample trade at a statistically significant discount relative to their singlesegment counterparts. The mean discount ranges between -0.11 and -0.28 for different years between 1989 and 1996, and averages - 0.19 over the whole period. These figures are smaller than those reported by Lang and Stulz (1994) and Servaes (1996) for the 1980s and the 1960s, respectively, using a similar measure. The results are consistent, however, with the general downward trend in the size of the diversification discount reported by Lang and Stulz (1994) for the late 1980s. 
Insert Table 4 about here

Column 3 of Table 4 reports the corresponding estimates obtained on business unit data. As shown, when excess values are estimated on the same sample using business unit data, diversified firms trade at an average premium relative to single-business firms. The premium ranges between 0.07 and 0.28 , with a $1989-1996$ period average of $0.20 .{ }^{17}$ In other words, the finding of a "diversification discount" gets completely reversed when a more consistent and objective definition of diversified firms' constituent units is used. This suggests that one should be wary of inferences about the effect of diversification on firm value based only on segment data, since the definition of diversification is itself contingent on the data source used. Before reaching any further conclusion, however, a number of robustness checks need to be performed.

\subsection{Robustness of the comparison between diversified firms' excess value estimates on business unit vs. segment data}

The results in Table 4 have been obtained by computing diversified firms' excess value in as similar a way as possible to earlier studies. Nonetheless, several variations of this computation are plausible and have been used in the prior literature. In this subsection I examine the robustness of the difference between the premium and the discount to these variations. The results of the robustness checks are reported in Table 5. To facilitate the comparison, the first row of Table 5 reproduces the last row of Table 4 (the pooled results), and only the pooled estimates are reported for each variation. However, the results for individual years are similar and are available from the author upon request.

Insert Table 5 about here

\footnotetext{
${ }^{17}$ Similar results are obtained using medians instead of averages, but the Census Bureau's disclosure policy prevent me from reporting such medians or any other statistic containing information on individual firms.
} 
First, the imputed $q \mathrm{~s}$ for diversified firms on which the estimates in Table 4 are based have been constructed using assets as weights for segments (following earlier studies), but employment as weights for business units (because it is the only measure of size available for business units). This may raise a concern about the comparability of the excess value measures used on the different data, and so the excess value on segment data has been re-estimated using segment employment as weights. The second row in Table 5 shows, however, that the discount at which the multi-segment firms in the sample trade relative to single-segments is even larger if employment is used (- 0.24 vs. - 0.19). In this sense, the reported premium for multi-business firms can be considered as a conservative estimate.

Second, the industry averages used as benchmarks or imputed $q$ s for each segment have been computed at the 4 digit-SIC code level whenever possible. The results reported in some of the earlier studies, however, are based on 3-digit SIC-based industry averages even for those industries for which 4 digit averages could be computed. For this reason, I recompute the excess values on both segment and business unit data using 3-digit level industry averages. The third row of Table 5 shows that, while the discount based on segment data remains practically unchanged (- 0.18 vs. -0.19 ), the premium found on business unit data becomes even higher (0.27 vs. 0.20$)$.

A third potential concern is that the differences in results between the two data sources may largely be due to the screening criteria adopted from earlier studies. Accordingly, I reestimate excess values on both sources without eliminating outliers, and without eliminating firms with financial segments or business units. The results of these two variations are shown in rows 4 and 5 of Table 5, respectively. It can be seen that by not eliminating outliers, the differences in results are greatly exacerbated - the discount becomes -0.29 whereas the 
premium becomes 0.91 . On the other hand, the inclusion of firms with financial activities does not affect the difference between results, as it lowers he discount by exactly the same amount by which it increases the premium (0.02).

As a fourth robustness check, I also compute excess values from both data sources on a subsample of pure manufacturing firms (i.e. firms with no segments or business units out of the 2000-3999 SIC code range). These are reported in row 6 of Table 5. Using a similar sample, Schoar (2000) compares the average diversification discount obtained from Compustat segment data to that based on LRD data (aggregating establishments within a firm by SIC code in the same way the business units in this paper are constructed). She finds the excess value of diversified firms to be smaller when estimated on LRD data, but still negative and significant, which is particularly puzzling given that she finds a productivity premium for the same firms. Accordingly, she concludes that "even though segment measures from Compustat might be very coarse, they do not seem biased in such a way as to fundamentally reverse the outcome on the diversification discount" (p.33). Somewhat consistently with her results, I find that pure manufacturing firms are the only subsample within the BITS-Compustat Common Sample where the diversification premium is relatively small and statistically insignificant. ${ }^{18}$ My use of BITS as opposed to LRD, however, reveals that, when establishments and firms from all sectors of the economy are allowed into the picture, the conclusion arrived at is exactly the opposite.

\subsection{Robustness of the diversification premium to making business units more comparable to} segments

A more fundamental question that may be asked, especially in light of the contrast between the results obtained on BITS data and those obtained on segment data, relates to the 
institutional definition of segment. The question is: Are segment data "worse" or just different? To recall, the three key differences between segments and business units that arise by design are: (1) The "10 segments maximum" constraint that results from the $10 \%$ materiality threshold; (2) the "permission" to group related activities into a common segment; and (3) the "obligation" to group vertically related activities into a common segment. ${ }^{19}$ Leaving aside the noise or bias that I have argued each of these rules generate, it might be noted that they are sensible rules after all not just for reporting practice but also for research purposes.

For instance, if $95 \%$ of a firm's activity is in industry $\mathrm{A}$ and the remaining $5 \%$ is in industry B, it may seem more reasonable to classify the firm as single-segment (as would be done in Compustat) than to classify it as diversified (as would be done with the business units I have constructed using BITS data). Accordingly, as a fifth robustness check, I re-construct the business units in my dataset by imposing on them a $10 \%$ materiality condition similar to Compustat's (in this case applied to employment), and I estimate the effect of diversification as before. To avoid distorting the weights, I substitute the within-firm sum of the new business units' employment for the firm's total employment figure.

The results of this analysis are reported in row 7 of Table 5. Once again, I find a premium which is larger than the one stemming from the original definition of business units ( 0.43 vs. 0.20). In fact, it is the largest of all premia found in my robustness checks, except for the 0.91 that results from not eliminating outliers. This finding lends support to my claim that the discount found when using segment-level data is due to the noise and bias generated by such

\footnotetext{
${ }^{18}$ I find my results for pure manufacturing firms "somewhat consistent" with Schoar's because the time period in her sample is 1977-1995 and, as noted before, the size of the segment data-based diversification discount has declined over time since the mid-1980's.

${ }^{19}$ As Davis and Duhaime put it, "either vertical integration $O R$ relatedness are necessary conditions for assigning two businesses to a single segment; vertical integration is also a sufficient condition for assigning two businesses to a single segment, but relatedness is not" (1992: 512).
} 
data, and not by the imposition of a (reasonable or not) materiality threshold for segment definition.

Regarding the ability of firms to group related activities into a common segment, I have argued in Section 1 that this creates (a) noise, because the aggregation of activities into any given SIC code differs across firms, and (b) bias, because high-performing related diversifiers may show up in the data as undiversified firms. Leaving aside the noise issue, it may be argued that the "bias" is not really a problem, since all it means is that segment data lead the researcher to estimate the pure "conglomerate discount" (i.e. the value effect of unrelated diversification). In contrast, BITS business unit data lead the researcher to estimate the more broadly defined "diversification discount" (or premium), i.e. the value effect of diversification regardless of whether it is related or unrelated. Since there is no obvious reason to prefer one over the other, I re-estimate diversified firms' excess value when business units are constructed at the 2 and 3 digit levels. These estimates capture, respectively, the effects of unrelated and of "semi-related" diversification. At the same time, they are free from the noise that arises in segment data due to the fact that, when two or more activities with different SIC codes are grouped together, they are assigned one common (primary) 4-digit SIC code.

Rows 8 and 9 of Table 5, where these estimates are reported, show that the average effect of diversification on corporate value is positive for all degrees of relatedness. In fact, and contrary to what would be expected from the evidence about diversification's effect on profitability, the value effect is somewhat more positive the greater the degree of unrelatedness (0.27 when business units are constructed at the 2-digit SIC level, 0.25 when they are constructed at the 3-digit level). 
The definitional requirement for firms to group vertically related activities into a common segment raises a similar concern. For instance, if $\mathrm{A}$ is an input for $\mathrm{B}$, consider the case of a firm that has $50 \%$ of its assets in industry A and $50 \%$ in industry B and transfers most of it's Aoutput internally (as opposed to selling it to outside customers). The firm would be classified as diversified according to BITS business unit data, but as undiversified in Compustat. Therefore, a fundamental difference between both data sources is that the former treats vertical integration as a form of corporate diversification, whereas the latter does not. Put differently, BITS business unit data lead the researcher to estimate the value effect of diversification in operations, whereas Compustat segment data lead the researcher to estimate the effect of diversification in markets. Clearly, these are two different concepts, and they need not be correlated. A vertically integrated firm maybe highly diversified in its operations, but very narrowly focused on one market. On the other hand, a very outsourcing-oriented firm may be highly diversified in its markets, but very narrowly focused on one type of operation (say, product design).

Again, leaving aside the problem of the noise created by the fact that a given SIC code may entail very different levels of vertical integration across firms, there is no obvious reason to prefer investigating one of the two types of diversification over the other. Therefore, as a seventh robustness check, I reconstruct BITS business units so that all potentially vertically related activities within the firm are included within a common business unit. Because BITS provides no information about internal transfers, I cannot determine the true extent of vertical integration of firms. Instead, I use Input-Output data to construct an inter-industry vertical relatedness table. Following Matsusaka (1993) and Schoar (2000), each pair of industries are considered vertically related if they receive $5 \%$ or more of their inputs or supply $5 \%$ or more of their output to each other. In my re-constructed business units, every pair or group of activities in a firm that are 
related according to this definition are considered a single business unit, and assigned the SIC code of the activity that has the largest number of employees among those included in the same unit. The last row of Table 5 shows that the estimate that results from this redefinition of business units is a 0.22 premium. Therefore, my findings appear to be robust to whether diversification is measured in the firm's operations or in its markets.

\subsection{Robustness of the diversification premium to different measures of excess value and} diversification, and to the inclusion of control variables

As a final robustness check on my results, I estimate pooled univariate and multivariate regressions of the two different excess value measures on the six different diversification measures described before. Table 6, where these regression results are reported, shows that the size of the diversification premium varies depending on the measures and specification used, but the premium is always positive and significant (the sign for the Herfindahl index is negative because this measure takes greater values the lower the degree of diversification).

Insert Table 6 about here

In summary, the finding that diversified firms trade at a premium when using business unit data seems robust to a diverse set of sensitivity analyses. Since, in contrast to segments, business units are defined objectively and consistently across firms, and are free from accounting and managerial reporting conventions, it seems fair to conclude that the finding of a diversification discount is just an artifact of the underlying data.

\section{Conclusion}

This paper argues that the finding that diversified firms trade at a discount raises an important economic puzzle, and explores whether the finding may be an artifact of the data or 
methods used to construct it. I use a new establishment-level Census database (BITS), which covers the whole U.S. economy between 1989 and 1996, to construct better measures of diversification. These data allow me to determine the breakdown of firms' activities by industry consistently across firms. In contrast, the segment data used in prior studies of the diversification discount typically group into each segment different activities, and different combinations of activities for different firms. More importantly, my data are not subject to the biases inherent to segment reporting. The use of this valuable new data source in a sample where segment data yield a discount reveals that diversified firms actually trade at a large and statistically significant premium relative to non-diversified firms in the same industries. The premium is robust to a number of variations in the method, sample, and measures of excess value and diversification.

As part of my robustness checks, I recreate the institutional features of segment definition in my dataset, to the extent to which this is feasible. I find that a premium is also found on BITS data when business units are constructed (1) following the $10 \%$ materiality rule, (2) at the 2 and 3 digit levels in order to group related activities within the same unit, and (3) including vertically related activities within the same unit. Besides strengthening my results, these analyses also throw some light into which of the three possible problems with segment data identified in section 1 may be responsible for the observed difference between the premium and the discount. The bias inherent to the institutional definition of segments does not seem to have played a role. Therefore, the difference seems to result from the noise inherent to segment data and/or from the bias due to managerial discretion in segment reporting. Further research might help unbundle these two sources. In any case, my results certainly call into question much of the received wisdom about the diversification discount, and more generally the adequacy of segment data for large sample research within firms. 


\section{References}

Acs, Zoltan, and Catherine Armington, 1998, Longitudinal Enterprise and Establishment Microdata (LEEM) Documentation, CES Discussion Paper 98-9, Center for Economic Studies, U.S. Bureau of the Census, Washington D.C.

Acs, Zoltan, Catherine Armington, and Alicia Robb, 1999, Measuring job flow dynamics in the U.S. economy, CES Discussion Paper 99-1, Center for Economic Studies, U.S. Bureau of the Census, Washington D.C.

American Institute of Certified Public Accountants (AICPA), 1994, Improving business reporting-A customer focus, Report of the AICPA Special Committee on Financial Reporting, AICPA, New York, NY.

Amihud, Yakov, and Baruch Lev, 1981, Risk reduction as a managerial motive for conglomerate mergers, Bell Journal of Economics 12, 605-617.

Armington, Catherine, 1998, Statistics of U.S. Businesses-Microdata and tables of SBA/Census data on establishments by firm size. Office of Advocacy, U.S. Small Business Administration, Washington D.C.

Armington, Catherine, and Alicia Robb, 1998, Mergers and acquisitions in the U.S.: 19901994. Office of Advocacy, U.S. Small Business Administration, Washington D.C.

Armington, Catherine, and Alicia Robb, 1999, An investigation into the volume and impact of business acquisition activity in the U.S.: 1990-1994. Office of Advocacy, U.S. Small Business Administration, Washington D.C.

Association for Investment Management Research (AIMR), 1993, Financial reporting in the 1990s and beyond: A position paper of the AIMR, prepared by Peter H. Knutson for the Financial Accounting Policy Committee, AIMR, Charlottesville, VA.

Barney, Jay B., 1996, Gaining and Sustaining Competitive Advantage. Addison-Wesley, Reading, MA.

Berger, Philip G., and Eli Ofek, 1995, Diversification's effect on firm value, Journal of Financial Economics 37, 39-65.

Berger, Philip G., and Eli Ofek, 1996, Bustup takeovers of value-destroying diversified firms, Journal of Finance 51, 1175-1200.

Bernardo, Antonio E., and Bhagwan Chowdry, 1999, Resources, real options, and corporate strategy, Unpublished working paper, University of California, Los Angeles.

Burch, Timothy, Vikram Nanda, and M.P. Narayanan, 2000, Industry structure and the conglomerate "discount": Theory and evidence, Unpublished working paper, University of Michigan.

Campa, José Manuel, and Simi Kedia, 1999, Explaining the diversification discount, Working paper, New York University, New York City, NY, and Harvard Business School, Boston, MA.

Chevalier, Judith A., 1999, Why do firms undertake diversifying mergers? An examination of the investment policies of merging firms, Working paper, University of Chicago. 
Chung, Kee H. and Stephen W. Pruitt, 1994, A simple approximation of Tobin's $q$, Financial Management 23, 70-74.

Comment, Robert, and Gregg A. Jarrell, 1995, Corporate focus and stock returns, Journal of Financial Economics 37, 67-87.

Darrough, Masako, and Neal M. Stoughton, 1990, Financial disclosure policy in an entry game, Journal of Accounting and Economics , 12: 219-243

Davis, Rachel, and Irene M. Duhaime, 1992, Diversification, vertical integration, and industry analysis: New perspectives and measurement," Strategic Management Journal 13, 511-524.

Denis, David J., Diane K. Denis, and Atulya Sarin, 1997, Agency problems, equity ownership and corporate diversification, Journal of Finance 52, 135-160.

Feltham, Gerald A, Frank B. Gigler, and John S. Hughes, 1992, The effects of line-ofbusiness reporting on competition in oligopoly settings, Contemporary Accounting Research 9: 1-23.

Feltham, Gerald A, and Jim Z. Xie, 1992,Voluntary financial disclosure in an entry game with continua of types, Contemporary Accounting Research, 9: 46-80.

Fluck, Zsuzsanna, and Anthony W. Lynch, 1999, Why do firms merge and then divest? A theory of financial synergy, Journal of Business 72, 319-346.

Graham, John R., Michael Lemmon, and Jack Wolf, 1999, Does corporate diversification destroy value?, Unpublished working paper, Duke University.

Harris, Mary S., 1998, The association between competition and managers' business segment reporting decisions, Journal of Accounting Research 36: 111-128.

Hatfield, Donald E., Julia P. Liebeskind, and Timothy C. Opler, 1996, The effects of corporate restructuring on aggregate industry specialization, Strategic Management Journal 17: 55-72.

Hayes, Rachel M., and Russell Lundholm, 1996, Segment reporting to the capital market in the presence of a competitor, Journal of Accounting Research 31: 261-279.

Heckman, James, 1979, Sample selection bias as a specification error, Econometrica, 47: $153-161$.

Herrmann, Don, and Wayne B. Thomas, 2000, An analysis of segment disclosures under SFAS No. 131 and SFAS No. 14, Accounting Horizons 14: 287-302.

Hubbard, R. Glenn, and Darius Palia, 1999, A reexamination of the Conglomerate Merger Wave in the 1960s: An internal capital markets view, Journal of Finance 54, 11311152.

Hyland, David C., 1997, Why firms diversify, An empirical examination, unpublished doctoral dissertation, Ohio State University, Columbus, Ohio.

Jacquemin, Alexis P., and Charles H. Berry, 1979, Entropy measure of diversification and corporate growth, Journal of Industrial Economics, 27: 359-369.

Lamont, Owen, 1997, Cash flow and investment: Evidence from internal capital markets, 
Journal of Finance 52, 83-109.

Lang, Larry H.P., and René M. Stulz, 1994, Tobin's q, corporate diversification, and firm performance, Journal of Political Economy 102, 1248-1280.

Lemelin, André, 1982, Relatedness in the patterns of interindustry diversification, Review of Economics and Statistics 64, 646-657.

Lichtenberg, Frank R., 1991, The managerial response to regulation of financial reporting for segments of a business enterprise, Journal of Regulatory Economics 3: 241-249.

Lichtenberg, Frank R., 1992, Industrial de-diversification and its consequences for productivity, Journal of Economic Behavior and Organization 18, 427-438.

Liebeskind, Julia P. , and Timothy C. Opler, 1992, The causes of corporate refocusing, Working paper, University of Southern California, and Ohio State University

MacDonald, James M., 1985, R\&D and the directions of diversification, Review of Economics and Statistics 67, 583-590.

Maksimovic, Vojislav, and Gordon Phillips, 1999, Do conglomerate firms allocate resources inefficiently?, Unpublished working paper, University of Maryland.

Matsusaka, John G., 1993, Takeover motives during the conglomerate merger wave, RAND Journal of Economics 24, 357-379.

Matsusaka, John G., 1998, Corporate diversification, value maximization, and organizational capabilities, Working paper, University of Southern California, Los Angeles, CA.

Merino, Fernando, and Diego R. Rodríguez, 1997, A consistent analysis of diversification decisions with non-observable firm effects, Strategic Management Journal 18, 733743.

Montgomery, Cynthia A., 1994, Corporate diversification, Journal of Economic Perspectives 8, 3, 163-178.

Montgomery, Cynthia A., and Sam Hariharan, 1994, Diversified expansion by large established firms, Journal of Economic Behavior and Organization 15, 71-89.

Morck, Randall, Andrei Shleifer, and Robert W. Vishny, 1990, Do managerial objectives drive bad acquisitions?, Journal of Finance 45, 31-48.

Piotroski, Joseph D., 2000, Discretionary segment reporting decisions and the precision of investors beliefs, Unpublished working paper, University of Chicago.

Rajan, Raghuram, Henri Servaes, and Luigi Zingales, 2000, The cost of diversity: The diversification discount and inefficient investment, Journal of Finance 60, 35-80.

Robb, Alicia, 2000, New data for dynamic analysis: The Business Information Tracking Series (BITS). Office of Advocacy, U.S. Small Business Administration, Washington D.C.

Rumelt, Richard P., 1974, Strategy, Structure, and Economic Performance, Division of Research, Harvard Business School, Boston, MA.

Scharfstein, David S., 1998, The dark side of internal capital markets II: Evidence from 
diversified conglomerates, Working paper 6352, National Bureau of Economic Research, Cambridge, MA.

Scharfstein, David S., and Jeremy C. Stein, 1997, The dark side of internal capital markets: Divisional rent-seeking and inefficient investment, Working paper 5969, National Bureau of Economic Research, Cambridge, MA.

Schipper, Katherine, and Rex Thompson, 1983, Evidence on the capitalized value of merger activity for merging firms, Journal of Financial Economics 11, 85-119.

Schoar, Antoinette S., 1999, Effects of corporate diversification on productivity, Unpublished working paper, University of Chicago.

Servaes, Henri, 1996, The value of diversification during the conglomerate merger wave, Journal of Finance 51, 4, 1201-1225.

Shin, Hyun-Han, and René M. Stulz, 1995, Are internal capital markets efficient?, Quarterly Journal of Economics 113, 531-552.

Shleifer, Andrei, and Robert W. Vishny, 1989, Managerial entrenchment, The case of manager-specific investments, Journal of Financial Economics 25, 123-139.

Silverman, Brian S., 1999, Technological resources and the direction of corporate diversification: Toward an integration of the resource-based view and transaction cost economics, Management Science 45, 1109-1124.

Springsteel, Ian, 1998, Sliced, diced, and still obscure: New rules on reporting business segment information set by the Financial Accounting Standards Board, CFO: The Magazine for Senior Financial Executives (February): 85.

Street, Donna L., Nancy B. Nichols, and Sidney J. Gray, 2000, Segment disclosures under SFAS No. 131: Has business segment reporting improved?, Accounting Horizons 14: 259-285.

Stulz, René M., 1990, Managerial discretion and optimal financing policies, Journal of Financial Economics 26, 3-27.

Villalonga, Belén, 1999, Does diversification cause the "diversification discount"?, Unpublished working paper, University of California, Los Angeles.

Villalonga, Belén, 2000a, Matching BITS to Compustat: Towards richer data for large sample research within firms, Unpublished manuscript, University of California, Los Angeles.

Villalonga, Belén, 2000b, An empirical analysis of diversification motives, Unpublished manuscript, University of California, Los Angeles.

Whited, Toni M., 1999, Is it inefficient investment that causes the diversification discount?, Working paper, University of Maryland, College Park, MD.

Wulf, Julie, 1999, Influence and inefficiency in the internal capital market: Theory and evidence, Working paper, Wharton School, University of Pennsylvania, Philadelphia, PA.

Zuckerman, Ezra W., 1999, The categorical imperative: Securities analysts and the illegitimacy discount, American Journal of Sociology 104: 1398-1438. 
Table 1

Number of firms, segments, business units, and establishments in BITS, Compustat, and in the Common Sample

BITS refers to the Business Information Tracking Series of the U.S. Census Bureau. BITS covers all U.S. private sector establishments with positive payroll in any year between 1989 and 1996, from both public and private firms. Compustat covers all firms that are publicly traded in U.S. stock markets. The BITS-Compustat Common Sample has been constructed by merging both databases to the extent to which this is feasible, as described in detail in Villalonga (2000) and summarized in this paper. BITS defines a establishment is defined as "a single physical location where business is conducted or where services or industrial operations are performed," and a firm as "the largest aggregation of business legal entities [which are the legal owners of establishments] under common ownership and control." A segment is defined in SFAS 14 as "a component of an enterpris e engaged in providing a product or service or a group of related products and services primarily to unaffiliated customers (i.e. customers outside the enterprise) for a profit." A business unit is defined in this paper as the aggregation of all of a firm's establishments with a common 4digit SIC code. The numbers of firms and segments reported for Compustat result from merging Compustat company and segment level data for all firms included in the active and research company-level files. Firms that are included in the company-level files but not in the segment-level files are considered single-segment firms, and are assigned the company's primary 4digit SIC code (DNUM) as their industry code. Segments from firms that are included in both the company and segment-level files are assigned the segment's primary 4digit SIC code (SSIC1) as their industry code. "Net" refers to the number of different units (firms, establishments, etc.) regardless of the year(s) in which they appear in the sample.

\begin{tabular}{|c|c|c|c|c|c|c|c|c|c|}
\hline \multirow[b]{2}{*}{ Year } & \multicolumn{3}{|c|}{ BITS } & \multicolumn{2}{|c|}{ Compustat } & \multicolumn{4}{|c|}{ Common Sample } \\
\hline & Establishments & Business Units & Firms & Segments & Firms & Establishments & Business Units & Segments & Firms \\
\hline 1989 & $6,063,857$ & $5,093,300$ & $4,978,250$ & 23,891 & 20,541 & 237,858 & 16,409 & 3,754 & 2,297 \\
\hline 1990 & $6,126,016$ & $5,136,656$ & $5,024,252$ & 23,794 & 20,541 & 243,120 & 16,521 & 3,926 & 2,438 \\
\hline 1991 & $6,155,181$ & $5,117,974$ & $5,005,347$ & 23,708 & 20,541 & 255,362 & 17,482 & 4,383 & 2,846 \\
\hline 1993 & $6,356,799$ & $5,271,301$ & $5,149,208$ & 23,725 & 20,541 & 266,534 & 17,821 & 4,667 & 3,191 \\
\hline 1994 & $6,465,057$ & $5,352,915$ & $5,232,956$ & 23,700 & 20,541 & 264,144 & 17,096 & 4,381 & 3,022 \\
\hline 1995 & $6,566,634$ & $5,439,734$ & $5,322,981$ & 23,650 & 20,541 & 256,958 & 16,354 & 4,199 & 2,899 \\
\hline 1996 & $6,699,635$ & $5,555,476$ & $5,439,206$ & 23,611 & 20,541 & 259,759 & 16,088 & 3,902 & 2,711 \\
\hline All years & $50,708,528$ & $42,139,652$ & $41,203,605$ & 189,808 & 164,328 & $2,054,978$ & 136,514 & 34,217 & 22,814 \\
\hline
\end{tabular}


Table 2

\section{Average number of firms per year by number of segments or business units}

BITS refers to the Business Information Tracking Series of the U.S. Census Bureau. BITS covers all U.S. private sector establishments with positive payroll in any year between 1989 and 1996, from both public and private firms. Compustat covers all firms that are publicly traded in U.S. stock markets. The BITS-Compustat Common Sample has been constructed by merging both databases to the extent to which this is feasible, as described in detail in Villalonga (2000) and summarized in this paper. BITS defines a establishment is defined as "a single physical location where business is conducted or where services or industrial operations are performed," and a firm as "the largest aggregation of business legal entities [which are the legal owners of establishments] under common ownership and control." A segment is defined in SFAS 14 as "a component of an enterprise engaged in providing a product or service or a group of related products and services primarily to unaffiliated customers (i.e. customers outside the enterprise) for a profit." A business unit is defined in this paper as the aggregation of all of a firm's establishments with a common 4digit SIC code. The numbers of firms and segments reported for Compustat result from merging Compustat company and segment level data for all firms included in the active and research company-level files. Firms that are included in the company-level files but not in the segment-level files are considered single-segment firms, and are assigned the company's primary 4digit SIC code (DNUM) as their industry code. Segments from firms that are included in both the company and segment-level files are assigned the segment's primary 4-digit SIC code (SSIC1) as their industry code.

\begin{tabular}{|c|c|c|c|c|c|c|c|c|}
\hline \multirow{3}{*}{$\begin{array}{l}\text { Number of } \\
\text { segments or } \\
\text { business units in } \\
\text { firm }\end{array}$} & \multirow{2}{*}{\multicolumn{2}{|c|}{$\begin{array}{c}\text { BITS } \\
\text { (Business Units) }\end{array}$}} & \multirow{2}{*}{\multicolumn{2}{|c|}{$\frac{\text { Compustat }}{\text { (Segments) }}$}} & \multicolumn{4}{|c|}{ Common Sample } \\
\hline & & & & & \multicolumn{2}{|c|}{ Business Units } & \multicolumn{2}{|c|}{ Segments } \\
\hline & Firms & $(\%)$ & Firms & $(\%)$ & Firms & $(\%)$ & Firms & $(\%)$ \\
\hline 1 & $5,089,196$ & (99) & 18,785 & (91) & 866 & (30) & 2,048 & (72) \\
\hline 2 & 41274 & $(0.8)$ & 904 & (4.4) & 416 & (15) & 411 & (14) \\
\hline 3 & 10360 & $(0.2)$ & 498 & $(2.4)$ & 315 & (11) & 242 & (8) \\
\hline 4 & 4092 & $(0.08)$ & 222 & (1.1) & 243 & (9) & 102 & (3.6) \\
\hline 5 & 1899 & $(0.04)$ & 82 & (0.4) & 162 & (6) & 34 & (1.2) \\
\hline 6 & 1038 & $(0.02)$ & 29 & $(0.14)$ & 125 & (4) & 9 & $(0.3)$ \\
\hline 7 & 625 & $(0.012)$ & 11 & $(0.05)$ & 98 & (3) & 4 & $(0.1)$ \\
\hline 8 & 419 & $(0.008)$ & 4 & $(0.02)$ & 86 & (3) & 0.5 & $(0.02)$ \\
\hline 9 & 291 & $(0.006)$ & 3 & $(0.02)$ & 65 & (2) & 0.9 & $(0.03)$ \\
\hline $10-19$ & 932 & $(0.018)$ & 3 & $(0.02)$ & 297 & (10) & 1.4 & $(0.05)$ \\
\hline $20-29$ & 200 & $(0.004)$ & 0 & (0) & 101 & (4) & 0 & (0) \\
\hline $30+$ & 125 & $(0.002)$ & 0 & (0) & 78 & (3) & 0 & (0) \\
\hline Total & $5,150,451$ & (100) & 20,541 & (100) & 2,852 & (100) & 2,852 & (100) \\
\hline
\end{tabular}


Table 3

\section{Firm employment, assets, and Tobin's q: Means and standard deviations}

Standard deviations are in parentheses. In italics is the number of non-missing observations (firm-years). $q$ is computed as the market value of common equity plus total assets minus the book value of common equity, divided by total assets. BITS, Compustat, the Common Sample, segment, and business unit are defined in Tables 1 and 2.

\begin{tabular}{|c|c|c|c|c|c|c|c|c|}
\hline \multirow{3}{*}{ Year } & \multirow{3}{*}{$\frac{\text { BITS }}{\text { Employment }}$} & \multicolumn{3}{|c|}{ Compustat } & \multicolumn{4}{|c|}{ Common Sample } \\
\hline & & \multirow[t]{2}{*}{ Empl. } & \multirow{2}{*}{$\begin{array}{r}\text { Assets } \\
\text { (\$ Million) }\end{array}$} & \multirow[t]{2}{*}{$q$} & \multicolumn{2}{|c|}{ Employment } & \multirow{2}{*}{$\begin{array}{l}\text { Assets }(\$ \\
\text { Million) }\end{array}$} & \multirow[t]{2}{*}{$q$} \\
\hline & & & & & BITS & Compustat & & \\
\hline \multirow[t]{3}{*}{1989} & 18 & 6,299 & 1,798 & 2.0 & 6,480 & 7,781 & 1,254 & 1.8 \\
\hline & (634) & $(25,541)$ & $(9,518)$ & $(4.1)$ & $(24,581)$ & $(29,085)$ & $(7,218)$ & (2.3) \\
\hline & $4,978,250$ & 6,719 & 7,617 & 6,081 & 2,297 & 2,297 & 2,297 & 2,297 \\
\hline \multirow[t]{3}{*}{1990} & 19 & 6,410 & 1,947 & 1.9 & 6,148 & 7,311 & 1,264 & 1.6 \\
\hline & (639) & $(25,698)$ & $(10,441)$ & (11.4) & $(23,990)$ & $(27,807)$ & $(7,511)$ & (1.9) \\
\hline & $5,024,252$ & 6,630 & 7,660 & 6,011 & 2,438 & 2,438 & 2,438 & 2,438 \\
\hline \multirow[t]{3}{*}{1991} & 18 & 6,164 & 1,980 & 2.3 & 5,455 & 6,556 & 1,161 & 2.1 \\
\hline & (633) & $(25,176)$ & $(10,785)$ & (8.6) & $(21,953)$ & $(26,124)$ & $(7,245)$ & (2.9) \\
\hline & $5,005,347$ & 6,786 & 7,820 & 6,107 & 2,846 & 2,846 & 2,846 & 2,846 \\
\hline \multirow[t]{3}{*}{1992} & 18 & 5,945 & 2,008 & 2.4 & 4,737 & 5,714 & 1,060 & 2.1 \\
\hline & (629) & $(24,560)$ & $(11,256)$ & (12.9) & $(20,243)$ & $(24,116)$ & $(7,347)$ & $(2.4)$ \\
\hline & $5,051,405$ & 7,132 & 8,242 & 6,380 & 3,410 & 3,410 & 3,410 & 3,410 \\
\hline \multirow[t]{3}{*}{1993} & 18 & 5,643 & 2,035 & 2.3 & 4,970 & 5,886 & 1,132 & 2.1 \\
\hline & $(625)$ & $(23,606)$ & $(12,561)$ & (13) & $(20,821)$ & $(24,474)$ & $(7,875)$ & (2.1) \\
\hline & $5,149,208$ & 7,692 & 9,438 & 7,515 & 3,191 & 3,191 & 3,191 & 3,191 \\
\hline \multirow[t]{3}{*}{1994} & 18 & 5,807 & 2,166 & 2.0 & 5,302 & 6,193 & 1,187 & 1.9 \\
\hline & (630) & $(25,829)$ & $(13,853)$ & (14.4) & $(21,377)$ & $(25,474)$ & $(7,508)$ & (1.5) \\
\hline & $5,232,956$ & 7,928 & 9,932 & 8,027 & 3,022 & 3,022 & 3,022 & 3,022 \\
\hline \multirow[t]{3}{*}{1995} & 19 & 5,856 & 2,289 & 3.8 & 5,555 & 6,426 & 1,288 & 2.1 \\
\hline & $(641)$ & $(26,298)$ & $(15,938)$ & $(94.5)$ & $(21,888)$ & $(26,457)$ & $(8,353)$ & $(2.3)$ \\
\hline & $5,322,981$ & 8,222 & 10,891 & 8,847 & 2,899 & 2,899 & 2,899 & 2,899 \\
\hline \multirow[t]{3}{*}{1996} & 19 & 5,873 & 2,520 & 3.9 & 5,960 & 7,140 & 1,489 & 2.0 \\
\hline & (647) & $(26,214)$ & $(18,138)$ & (94.7) & $(22,605)$ & $(28,437)$ & $(9,366)$ & (1.9) \\
\hline & $5,439,206$ & 8,659 & 11,082 & 9,529 & 2,711 & 2,711 & 2,711 & 2,711 \\
\hline \multirow[t]{3}{*}{ All firm-years } & 19 & 5,981 & 2,122 & 2.7 & 5,509 & 6,545 & 1,221 & 2.0 \\
\hline & $(635)$ & $(25,405)$ & $(13,522)$ & $(53.9)$ & $(22,060)$ & $(26,360)$ & $(7,831)$ & $(2.2)$ \\
\hline & $41,203,605$ & 59,768 & 72,682 & 58,497 & 22,814 & 22,814 & 22,814 & 22,814 \\
\hline \multicolumn{9}{|l|}{ of which: } \\
\hline \multirow[t]{3}{*}{$\begin{array}{l}\text { - Diversified } \\
\text { (multi-segment) }\end{array}$} & & 13,713 & 4,181 & 1.8 & 10,656 & 12,994 & 3,098 & 1.5 \\
\hline & & $(36,957)$ & $(14,601)$ & $(16.7)$ & $(32,610)$ & $(36,175)$ & $(13,681)$ & (1.1) \\
\hline & & 13,106 & 14,020 & 12,270 & 6,439 & 6,439 & 6,439 & 6,439 \\
\hline \multirow[t]{3}{*}{ (multi-business) } & 727 & & & & 7,804 & 9,230 & 1,723 & 1.6 \\
\hline & $(5,750)$ & & & & $(26,100)$ & $(31,192)$ & $(9,334)$ & (1.2) \\
\hline & 490,037 & & & & 15,888 & 15,888 & 15,888 & 15,888 \\
\hline \multirow{4}{*}{$\begin{array}{l}\text {-Undiversified } \\
\text { (single-segment) }\end{array}$} & & & & & & & & \\
\hline & & 3,810 & 1,630 & 2.9 & 3,486 & 4,009 & 483 & 2.2 \\
\hline & & $(20,533)$ & $(13,203)$ & (60) & $(15,664)$ & $(20,756)$ & $(3,149)$ & (2.5) \\
\hline & & 46,662 & 58,662 & 46,227 & 16,375 & 16,375 & 16,375 & 16,375 \\
\hline (single-business) & 10 & & & & 245 & 387 & 68 & 2.8 \\
\hline & (63) & & & & $(646)$ & $(1,610)$ & $(448)$ & (3.5) \\
\hline & $40,713,568$ & & & & 6,926 & 6,926 & 6,926 & 6,926 \\
\hline
\end{tabular}


Table 4

\section{Diversified firms' excess value in the BITS-Compustat Common Sample}

Diversified firms' excess value is computed as the mean difference in individual excess values between diversified (multi-segment or multi-business) firms and non-diversified (single-segment or single-business) firms. Excess value is computed as the difference between the firm's Tobin's $q$ and its imputed $q$. Tobin's $q$ is computed as the market value of common equity plus total assets minus the book value of common equity, divided by total assets. A firm's imputed $q$ is the size-weighted average of the hypothetical $q$ 's of its segments (business units). Segment size is measured by segment assets; business unit size is measured by business unit employment. A segment's (business unit's) hypothetical $q$ is the average $q$ of all singlesegment (single-business) firms in its industry in any given year. Industry averages are computed at the 4 digit-SIC code level whenever possible. Firms with segments (business units) in financial services have been excluded from the sample. BITS, Compustat, the Common Sample, segment, and business unit are defined in the footnotes to Tables 1 and 2.

\begin{tabular}{|c|c|c|c|c|c|c|}
\hline \multirow[b]{3}{*}{ Year } & \multicolumn{3}{|c|}{ Segment data } & \multicolumn{3}{|c|}{ Business Unit data } \\
\hline & \multirow{2}{*}{$\begin{array}{r}\text { Mean } \\
(t \text {-stat. })\end{array}$} & \multicolumn{2}{|c|}{ Number of firms } & \multirow{2}{*}{$\begin{array}{r}\text { Mean } \\
(t \text {-stat. })\end{array}$} & \multicolumn{2}{|c|}{ Number of firms } \\
\hline & & Diversified & Non-div. & & Diversified & Non-div. \\
\hline 1989 & $\begin{array}{r}-0.28 \\
(-4.39)\end{array}$ & 602 & 1,393 & $\begin{array}{r}0.22 \\
(2.34)\end{array}$ & 782 & 550 \\
\hline 1990 & $\begin{array}{r}-0.15 \\
(-2.69)\end{array}$ & 631 & 1,493 & $\begin{array}{r}0.23 \\
(3.28)\end{array}$ & 812 & 611 \\
\hline 1991 & $\begin{array}{r}-0.26 \\
(-3.58)\end{array}$ & 656 & 1,785 & $\begin{array}{r}0.07 \\
(0.62)\end{array}$ & 947 & 800 \\
\hline 1992 & $\begin{array}{r}-0.23 \\
(-3.74)\end{array}$ & 691 & 2,288 & $\begin{array}{r}0.28 \\
(3.89)\end{array}$ & 1,121 & 1086 \\
\hline 1993 & $\begin{array}{r}-0.21 \\
(-3.14)\end{array}$ & 664 & 2,170 & $\begin{array}{r}0.21 \\
(2.89)\end{array}$ & 1,065 & 993 \\
\hline 1994 & $\begin{array}{r}-0.11 \\
(-1.98)\end{array}$ & 634 & 2,082 & $\begin{array}{r}0.17 \\
(2.62)\end{array}$ & 977 & 884 \\
\hline 1995 & $\begin{array}{r}-0.14 \\
(-1.89)\end{array}$ & 586 & 1,899 & $\begin{array}{r}0.18 \\
(2.25)\end{array}$ & 952 & 806 \\
\hline 1996 & $\begin{array}{r}-0.14 \\
(-1.78)\end{array}$ & 559 & 1,793 & $\begin{array}{r}0.20 \\
(2.62)\end{array}$ & 907 & 708 \\
\hline All & $\begin{array}{r}-0.19 \\
(-8.06)\end{array}$ & 5,023 & 14,903 & $\begin{array}{r}0.20 \\
(6.89)\end{array}$ & 7,563 & 6,438 \\
\hline
\end{tabular}


Table 5

\section{Robustness of the comparison between diversified firms' excess value estimates on business unit vs. segment data}

Diversified firms' excess value is computed as the average difference in excess values between diversified and non-diversified firms, pooling all firm-year observations in the sample (see footnote to Table 4 for more details). The sample is the BITS-Compustat Common Sample or subsets of it, as indicated. The outliers referred to in row 4 are those firms whose imputed $q$ is higher than four times (or lower than a fourth of) their true $q$. BITS, Compustat, the Common Sample, segment, and business unit are defined in the footnotes to Tables 1 and 2.

\begin{tabular}{|c|c|c|c|c|c|c|}
\hline \multirow[b]{3}{*}{ Robustness check } & \multicolumn{3}{|c|}{ Segment data } & \multicolumn{3}{|c|}{ Business Unit data } \\
\hline & \multirow{2}{*}{$\begin{array}{r}\text { Mean } \\
(t \text {-stat. })\end{array}$} & \multicolumn{2}{|c|}{ Number of firm-years } & \multirow{2}{*}{$\begin{array}{r}\text { Mean } \\
\text { (t-stat.) }\end{array}$} & \multicolumn{2}{|c|}{ Number of firm-years } \\
\hline & & Diversified & Non-div. & & Diversified & Non-div. \\
\hline 1. Excess value estimates in Table 4 & $\begin{array}{r}-0.19 \\
(-8.06)\end{array}$ & 5,023 & 14,903 & $\begin{array}{r}0.20 \\
(6.89)\end{array}$ & 7,563 & 6,438 \\
\hline 2. Using segment employment as weights on segment data & $\begin{array}{r}-0.24 \\
(-5.45)\end{array}$ & 1,298 & 14,613 & & & \\
\hline 3. Computing industry averages at 3 -digit SIC level & $\begin{array}{r}-0.18 \\
(-6.40)\end{array}$ & 5,023 & 14,903 & $\begin{array}{r}0.27 \\
(10.05)\end{array}$ & 7,706 & 6,377 \\
\hline 4. Not eliminating outliers & $\begin{array}{r}-0.29 \\
(-7.21)\end{array}$ & 5,251 & 15,513 & $\begin{array}{r}0.91 \\
(19.47)\end{array}$ & 12,956 & 6,702 \\
\hline 5. Not eliminating firms with financial segments (business units) & $\begin{array}{r}-0.17 \\
(-7.99)\end{array}$ & 6,016 & 14,904 & $\begin{array}{r}0.22 \\
(8.81)\end{array}$ & 9,940 & 6,627 \\
\hline 6. Pure manufacturing firms only & $\begin{array}{r}-0.16 \\
(-5.51)\end{array}$ & 3,214 & 10,212 & $\begin{array}{r}0.08 \\
(1.25)\end{array}$ & 1,445 & 3,185 \\
\hline 7. Applying $10 \%$ materiality condition to business units & & & & $\begin{array}{r}0.43 \\
(17.83)\end{array}$ & 9,249 & 6,749 \\
\hline 8. Constructing business units at the 2-digit SIC level & & & & $\begin{array}{r}0.27 \\
(12.48)\end{array}$ & 9,264 & 8,536 \\
\hline 9. Constructing business units at the 3 -digit SIC level & & & & $\begin{array}{r}0.25 \\
(9.86)\end{array}$ & 9,042 & 6,826 \\
\hline 10. Including vertically related activities in same business unit & & & & $\begin{array}{r}0.22 \\
(4.77)\end{array}$ & 12,494 & 1,533 \\
\hline
\end{tabular}




\section{Table 6}

\section{Robustness of the diversification premium to different measures of excess value and diversification, and to the inclusion of control variables}

Pooled OLS regressions. $N=16,567$ firm-year observations. $t$-statistics are in parentheses. Excess value is the difference (in Panel A) or the natural logarithm of the ratio (in Panel B) of a firm's Tobin's $q$ to its imputed $q$ (see footnote to Table 4 for more details). The Herfindahl index of diversification is $\mathrm{H}=\Sigma_{i} P_{i}{ }^{2}$, and the Total Entropy measure is $\mathrm{E}_{\mathrm{F}}=\boldsymbol{\Sigma}_{i} P_{i} \ln \left(1 / P_{i}\right)$, where $P_{i}$ is the proportion of a firm's assets in industry $i$. Both measures are computed at the 4-digit SIC level. Unrelated Entropy, $\mathrm{E}_{\mathrm{U}}$, is defined like $\mathrm{E}_{\mathrm{T}}$ but computed at the 2-digit SIC level. Related Entropy is defined as $\mathrm{E}_{\mathrm{R}}=\mathrm{E}_{\mathrm{T}}-\mathrm{E}_{\mathrm{U}}$. The sample is the BITS-Compustat Common Sample, excluding firms with business units in financial services, and firms whose imputed $q$ is higher than four times (or lower than a fourth of) their true $q$. BITS, Compustat, the Common Sample, segment, and business unit are defined in the footnotes to Tables 1 and 2.

Panel A: Dependent variable: Excess value, measured as difference

Measure of diversification

\begin{tabular}{|c|c|c|c|c|c|c|c|c|c|c|c|c|}
\hline & \multicolumn{2}{|c|}{ Dummy } & \multicolumn{2}{|c|}{ No. of bus. units } & \multicolumn{2}{|c|}{ Herfindahl } & \multicolumn{2}{|c|}{ Entropy (Total) } & \multicolumn{2}{|c|}{ Entropy (Related) } & \multicolumn{2}{|c|}{ Entropy (Unrelated) } \\
\hline & (1) & (2) & (3) & (4) & (5) & (6) & (7) & (8) & (9) & (10) & (11) & (12) \\
\hline \multirow[t]{2}{*}{ Intercept } & 0.00 & -0.02 & -0.04 & 0.09 & 0.67 & 1.03 & -0.04 & -0.02 & -0.00 & -0.01 & 0.07 & -0.03 \\
\hline & $(0.06)$ & $(-0.64)$ & $(-1.97)$ & (2.60) & (20.7) & $(17.42)$ & $(-2.26)$ & $(-0.65)$ & $(-0.24)$ & $(-0.23)$ & $(5.18)$ & $(-0.81)$ \\
\hline \multirow[t]{2}{*}{ Diversification } & 0.20 & 0.24 & 0.04 & 0.06 & -0.79 & -0.98 & 0.81 & 0.88 & 1.04 & 1.08 & 0.46 & 0.45 \\
\hline & (6.90) & (7.27) & (13.10) & (14.26) & $(-19.3)$ & $(-21.6)$ & (13.97) & (14.64) & (15.3) & (12.90) & $(6.26)$ & $(6.33)$ \\
\hline \multirow[t]{2}{*}{ Log of assets } & & 0.003 & & -0.05 & & -0.06 & & -0.01 & & -0.01 & & 0.02 \\
\hline & & $(-0.30)$ & & $(-4.82)$ & & $(-6.98)$ & & $(-1.37)$ & & $(-0.76)$ & & $(3.02)$ \\
\hline \multirow[t]{2}{*}{ EBIT / Sales } & & -0.001 & & -0.001 & & -0.001 & & -0.001 & & -0.001 & & -0.001 \\
\hline & & $(-3.48)$ & & $(-3.35)$ & & $(-3.56)$ & & $(-3.48)$ & & $(-3.51)$ & & $(-3.38)$ \\
\hline \multirow[t]{2}{*}{ Capex / Sales } & & -0.005 & & -0.004 & & -0.004 & & -0.004 & & -0.005 & & -0.005 \\
\hline & & $(-2.97)$ & & $(-2.91)$ & & $(-2.78)$ & & $(-2.91)$ & & $(-2.99)$ & & $(-3.05)$ \\
\hline
\end{tabular}

Panel B: Dependent variable: Excess value, measured as log of ratio

\begin{tabular}{|c|c|c|c|c|c|c|c|c|c|c|c|c|}
\hline & \multicolumn{12}{|c|}{ Measure of diversification } \\
\hline & \multicolumn{2}{|c|}{ Dummy } & \multicolumn{2}{|c|}{ No. of bus. units } & \multicolumn{2}{|c|}{ Herfindahl } & \multicolumn{2}{|c|}{ Entropy (Total) } & \multicolumn{2}{|c|}{ Entropy (Related) } & \multicolumn{2}{|c|}{ Entropy (Unrelated) } \\
\hline & (1) & (2) & (3) & (4) & (5) & (6) & (7) & (8) & (9) & (10) & (11) & (12) \\
\hline \multirow[t]{2}{*}{ Intercept } & -0.15 & -0.29 & -0.11 & -0.19 & 0.76 & 0.75 & -0.12 & -0.29 & -0.04 & -0.27 & 0.03 & -0.29 \\
\hline & $(-19.1)$ & $(-22.7)$ & $(-16.8)$ & $(-14.55)$ & (71.2) & (36.80) & $(-19.2)$ & $(-23.6)$ & $(-7.07)$ & $(-21.9)$ & (5.64) & $(-23.1)$ \\
\hline \multirow[t]{2}{*}{ Diversification } & 0.41 & 0.34 & 0.06 & 0.05 & -0.96 & -0.96 & 1.07 & 0.95 & 1.24 & 1.02 & 0.70 & 0.60 \\
\hline & (39.82) & (27.89) & (47.48) & (34.82) & $(-71.2)$ & $(-61.9)$ & (52.9) & (44.56) & $(47.1)$ & (33.31) & $(25.6)$ & (22.56) \\
\hline \multirow[t]{2}{*}{ Log of assets } & & 0.05 & & 0.02 & & 0.00 & & 0.05 & & 0.06 & & 0.08 \\
\hline & & (13.69) & & (7.18) & & $(0.92)$ & & (15.93) & & (18.97) & & (28.50) \\
\hline \multirow[t]{2}{*}{ EBIT / Sales } & & -0.0002 & & -0.0001 & & -0.0002 & & -0.0002 & & -0.0001 & & -0.0002 \\
\hline & & $(-1.44)$ & & $(-0.97)$ & & $(-1.53)$ & & $(-1.34)$ & & $(-1.39)$ & & $(-1.06)$ \\
\hline \multirow[t]{2}{*}{ Capex / Sales } & & -0.001 & & -0.001 & & -0.005 & & -0.001 & & -0.001 & & -0.001 \\
\hline & & $(-1.40)$ & & $(-1.45)$ & & $(-1.07)$ & & $(-1.36)$ & & $(-1.63)$ & & $(-1.73)$ \\
\hline
\end{tabular}

